\title{
Making Speech Therapy Aids for Children with Special Needs
}

\author{
Muhammad Noor Ahsin ${ }^{1}$, Ristiyani ${ }^{2}$, Dina Lusianti ${ }^{3}$ \\ \{noor.ahsin@umk.ac.id, ristiyani@umk.ac.id, dina.lusianti@umk.ac.id\} \\ Indonesian Education/Universitas Muria Kudus, Central Java, 59532, Indonesia 1,2 \\ Management/ Universitas Muria Kudus, Central Java, 59532, Indonesia ${ }^{3}$
}

\begin{abstract}
Speech therapy is an alternative to overcome the problem of speech disorders. The provision of speech therapy services and the manufacture of speech therapy visual aids for children with speech disorders are urgently needed. One of the learning innovations that can be implemented is by making speech therapy aids for children with special needs. The goal of this service activity is to broaden the knowledge and understanding of PBSI FKIP UMK academic community related to the learning innovations of children who experience speech impairment by using speech therapy aids for children with special needs and to bring up science and technology-based business units. The methods used include segmentation, production, finance and HR management. The products are number cards, alphabet cards, body part cards, daily activity cards, certain place sequence accordions, daily activity order sequences, and hand puppets.
\end{abstract}

Keywords: Teaching aids, Speech Therapy, Children with Special Needs

\section{Introduction}

Language as an instrument of communication plays a role in conveying messages from the speaker to the listener. Language competence at the mental level is then articulated through the speech organs. The process of language articulation involves a very complex system and includes various organs in the human body. Impairment or damage to the speech organs can cause disruption of normal communication (Handoko, 2014). [5]

The number of speech disorder sufferers in Kudus regency based on the data from the Statistics Agency (2015) from the Social, Manpower and Transmigration Office reached the total of 252 people. In detail, there were 18 from Kaliwungu district, 49 from Kota district, 29 from Jati district, 35 from Undaan district, 21 from Mejobo district, 18 from Jekulo district, 33 from Bae district, 31 from Gebog district, and 18 from Dawe district.

Speech and language disorders are one of the most common causes of developmental disorders in children. Speech delay is a major complaint that parents often worry about and complain about to doctors. This disorder seems increasing rapidly. Some reports mention the incidence of speech and language disorders ranging from $5-10 \%$ in schoolchildren. Children who experience delays in speech and language are at risk of learning difficulties, reading and writing difficulties that will cause lacking academic achievement in a whole that is possible to continue until young adulthood. Furthermore, adults with low academic achievement due to delays in speech and language will experience behavioral problems and psychosocial adjustments.

Because of such large impacts arising from language delays in pre-school age children, it is highly essential to optimize the process of language development in this period. 
Early detection of speech delays and disorders in pre-school age children is the most important action to assess the level of language development of children in order to minimize the difficulty in the learning process of the children when entering the school age. Some experts conclude that speech and language development can be used as the indicator of overall child development, including cognitive abilities and success in the learning process at school. The results of longitudinal studies show that the delay in language development is related to intelligence and reading later in life.

Handling speech delay requires quite a long time and good cooperation from parents. Some children do not get a good handling until the developmental problem becomes something that cannot be handled or has a significant impact on other things. Speech delay is often accompanied by other disorders in accordance with the disease such as hyperactivity, strange behavior, and difficulty to work with; thus, the treatment must begin with improving the behavior. After that, supportive therapies such as speech therapy, occupational therapy, sensory integration therapy, etc. can be given. The handling requires cooperation from various experts such as physiotherapists, occupational therapists and of course speech therapists (Sunanik, 2013). [11)

The ability to use a language and speak is the main tool to communicate for us as humans. When one of the speech instruments or organs is disrupted, the person's communication will also be interrupted. The more severe the disruption of the speech organs, the more severe the communication disruption experienced by a person. Language development follows a sequence that in general can be predicted despite the diversity between one and another, with the intention of developing children's communication ability. The majority of children's language development starts with crying. Children try to express their responses to various stimulants. After that, the children starts cooing, which refers to reciting meaningless sounds. Then, the children start learning speaking sentences with one word, like "mimik" (drink) which means that they need a drink because of thirst.

The classification of communication disorders included in the fields of speech therapy are as follows. The first is speech disorder (articulation). This is one type of communication behavior disorder due to one or several causes related to the function of observation (sensation and perception), neuromuscular function, speech organ condition, or environmental influence where the children have difficulty to use language sounds correctly. In this case, the problem lies in the meeting point of the articulation (point of articulation) or in the way of producing language sounds (manner of articulation). Speech difficulty is usually characterized by substitution, omission, distortion (unclear) and addition. Articulation development disorder includes the failure to pronounce one letter to several letters, often the omission or substitution of the sound of the letter, giving rise to an impression of speaking like a child. It can also be in the form of pitch, volume or sound quality disorders.

The second is language disorder. It is one type of communication behavior disorder where people with language disorders experience obstacles or difficulties in the process of symbolization (coding) and the use of linguistic rules used by their environment so that the sufferers experience obstacles in the development, barriers to receptive abilities, and barriers to expressive ability. This language disorder can occur due to lesions in the language centers in the cerebral cortex.

The third is sound disorder. This is one type of communication disorder that is characterized by disturbance in the process of sound production (phonation) that usually occurs due to organic and functional causes that affect the function of the larynx during phonation. Disturbances in the process of sound production can be characterized by interference in aspects of sounds, including: loudness, tone, and quality. Sound disorder can 
broadly be divided into 2 (two) namely dysphonia and aphonia: a) Dysphonia is a condition of communication disorders in the form of deviations or imperfections in sound production that are caused by organic and functional factors. These conditions include: (1) tone disorder, (2) interference and (3) quality disorder. b) Aphonia is a condition of communication disorder that is caused by the loss of sound source or a complete failure in producing sound.

The fourth is rhythm/fluency disorder. This is one type of disruptions in communication behavior that is characterized by the repetition of sounds or syllables and the extension and blocking when speaking. The existence of repetition, prolongation and blocking when talking that makes the sufferers unable to speak fluently. In general, it occurs due to psychosocial disorders or other causes that interfere/affect the neuromotor function of the speech organ. Rhythm/fluency disorders can be divided into 3, namely: 1) stuttering, 2) cluttering, 3) latah (exaggerated startle reaction including apparently imitative behavior).

The fifth is swallowing disorders (dysphagia). This disorder is a difficulty in swallowing which is divided into 3 (three) phases, i.e. oral phase, pharyngeal phase and esophageal phase, caused by pathological, psychogenic and neurological conditions. The causes of language development disorders are numerous and widespread, all of which range from the process of hearing, the transmission of impulses to the brain, brain, muscles or speech organs.

Several of the causes of speech disorders or speech delays are hearing disorders, speech organ disorders, mental retardation, genetic or chromosomal abnormalities, autism, selective mutism, functional delays, receptive aphasia and environmental deprivation. The detail of factors causing speech disorders can be described as follows: (1) Internal Factors. Various internal factors or biological factors of the body such as perception, cognition and prematurity factors are considered as factors causing speech delay in children; (2) Perception. The ability to distinguish incoming information is called perception. Perception develops in 4 aspects: growth, which includes the development of nerve cells and the whole system; stimulation, which comes in the form of input from the environment covering the entire sensory aspects; habit, which is the result of schemes that are often formed. Habit (habituation) makes a baby get a new stimulation which will then be stored and then released in the process of learning the child's language. Gradually, the child will learn new stimulations starting from touch, taste, smell and then vision and hearing; (3) Cognition. Children at this age are very active in organizing their experiences into general groups or larger concepts. Children learn to represent and symbolize ideas and concepts.

Speech therapy is a study of language, speech and voice disorders that aims to be utilized as the basis for making diagnosis and treatment. In its development, speech therapy covers a wider scope of understanding by studying matters related to the speaking process, including swallowing process, rhythmic disorders and neuromotor disorders of other articulation organs.

According to Sastra (2011) in Handoko (2014), handling speech disorders begins with identification of the patient that include the medical history, speaking ability, listening ability, cognitive abilities, and communication skills. Then, the treatment continues with the diagnosis of the patient's disorder. After obtaining the diagnosis results, then the appropriate therapy can be applied for the patient.

Speech therapy normally uses audio or video and mirrors. After the patient learns about the disorder, the therapist then teaches the ability to speak using methods appropriate to the patient's age. Children's speech therapy commonly uses approaches of games, dolls, roleplays, and pairing pictures or cards. Adult's speech therapy generally uses a direct method, which is through training and practice. Articulation therapy in adults focuses on assisting the 
patients to produce sounds correctly. This therapy usually includes the way to position the tongue properly, shape the jaw, and control the breath so that they can produce sounds correctly. For sound disorders, the therapy focuses on the way to produce good sounds and improve the behavior that results in vocal disorders. The types of therapy are as follows.

\section{1) Oral Motor Therapy}

This therapy uses exercises that do not involve talking process, such as drinking through a straw, kissing a balloon, or blowing a trumpet. This exercise aims to train and strengthen the muscles used for talking.

2) Computer-Based Therapy

Along with the technology development, language and speech pathologists develop various softwares that can help the process of speech disorder therapy, including: (1) Tiny EYE, which is software that allows speech therapy to be carried out remotely. The method used in this device is the same as the method used in face-to-face therapy; (2) Fast ForWord, which is software that is designed based on problems in the hearing process. This tool uses games that are designed to slow down the tempo of the sounds so that it allows the user to distinguish the sounds; (3) TWIST (Technology with Innovative Speech Therapy), which is software developed for speech therapy for stroke, brain tumors, and neurodegenerative disease sufferers, as well as children who experience speech disorders.

3) Melody Intonation Therapy

Melody intonation therapy can be implemented to stroke sufferers who experience language disorders. The music or melody used is usually of a slow tempo, with lyrics, and of different beats.

Method of Implementation

Speech Therapy Laboratory of Muria Kudus University with the Business Unit of Speech Therapy Aids at the Indonesian Language and Literature Education Study Program Faculty of Teacher Training and Education Muria Kudus University is a provider of speech therapy teaching aid products for children in Kudus and surrounding areas.

The continuity of supply and quality of raw materials for educative aids are guaranteed. The raw materials for educative aids are obtained from various shops in Kudus Regency. The raw materials for the production of speech therapy devices are supplied periodically every month according to production requirements. The raw materials are sengon (albizia chinensis) or waru (hibiscus tiliaceus) wood with guaranteed quality, paper, fabric, and so on.

The clients of Speech Therapy Laboratory PBSI UMK for education and training services are parents whose children have speech problems, speech therapy clinics in Kudus and Pati ex-residency. One of the partners invited to work together is Prima Medistra Utama clinic in Bae district, Kudus regency. PBSI UMK Speech Therapy Laboratory clients for training as a basis for the establishment of new entrepreneurs are students. The clients are always available and need assistance with consultation and product innovation guidance on speech therapy aids. Another client is Lentera Hati School. The school is a special school for Children with Special Needs with various types of problems.

a. Parents

Parents have an important role for children's education, especially for those who have children who have impaired speaking ability. Parents also become the clients of Speech Therapy Laboratory PBSI UMK. The main role of parents at home is assisting the children 
when learning at home. Parents whose children have speech disorders are our partners. Speech Therapy Laboratory PBSI UMK is in collaboration with the students' parents.

b. Educational observer

For educational observers, Speech Therapy Laboratory PBSI UMK provides a very interesting offer related to learning innovation, especially for children who have speech delays or problems.

c. Public

In accordance with language competence and language skills, the development of the quality of the public will be devoted to the field of educational services related to innovation and meaningful learning practices, especially speech therapy for children with special needs. This program offer aims to utilize the excess capacity of lecturers and facilities owned by Speech Therapy Laboratory PBSI UMK.

d. University students

Another line of business that will be developed by Speech Therapy Laboratory PBSI UMK is non-profit trainings for students. Training for students is directed as a service for PBSI UMK students. The students are trained to be able to establish new entrepreneurs in the field of education, especially in learning innovations using speech therapy aids and consulting services or speech therapy for children.

The product of Speech Therapy Laboratory PBSI UMK is PBSI Speech Therapy Speech Business Unit of Muria Kudus University that produces/serves:

Children's speech therapy aids that include alphabet cards, color cards, daily activity cards, body part cards, hand puppets, daily activity sequence accordions, certain place sequence accordions and miniatures of living objects.

Education and training services for the manufacture and development of speech therapy aids that include rules for registration procedures, training participant manuals, training books for developing speech therapy aids, training participant certificates, manuals of production equipment maintenance and speech therapy teaching aid media procedures, work instructions for work safety while producing aids, and cash flow of Speech Therapy Laboratory PBSI UMK.

1. Educational consulting services related to educational teaching aid innovations They include rules for registration procedures, consultation participant manuals, Cash Flow of Speech Therapy Laboratory PBSI UMK.

2. Student training

It includes the guidelines for establishing new entrepreneurship and guidelines for the assistance from Speech Therapy Laboratory PBSI UMK to new entrepreneurs.

The production plan is carried out in the following stages.

1) The stages of the production of educational aids:

a. Preparing the tools and materials

b. Planning the design of speech therapy aids

c. Assembling and producing speech therapy teaching aid processes and the manuals

d. Experts' validation to the speech therapy aids that are produced

2) The stages of education and training services:

a. Preparing the location and training equipment

b. Preparing the speech consultation training materials and modules

c. Promoting the trainings, parents, and educational observers through leaflets, brochures, product seminars, fanpages, websites, radio and local 
newspapers

d. Accepting the training candidates

e. Preparing the instructors and assistants

f. Implementing the trainings

g. Monitoring and evaluating every training by distributing response questionnaires from the participants

3) The stages of consultation services:

a. Preparing the location and consultation equipment

b. Promoting the consultation services, parents, and educational observers through leaflets, brochures, product seminars, fanpages, websites, radio and local newspapers

Results and Discussion

The Business Unit of Speech Therapy Speech Therapy for Children with Special Needs owned by Muria Kudus University is currently developing well. The place is located in Building L, on the 3rd floor of Muria Kudus University. The manufactured goods are as follows.

a. Alphabet Cards

The alphabet card aid produced by the Speech Therapy Aid Business Unit is almost the same as general alphabet cards. However, it has bigger size and brighter colors. This aid is sold for Rp. 55,000.00 per package.

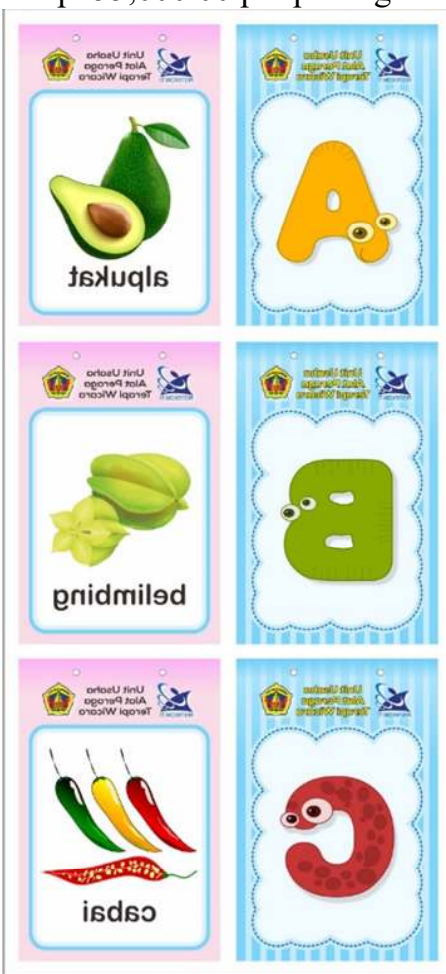

Figure 5.1 Alphabet Cards produced by ABK Speech Therapy Business Unit 
This product was sold as many as 344 packages in the first year. The shortcoming of this product is the paper material that is not thick enough.

b. Number Cards

The number card aid produced by the Speech Therapy Aid Business Unit is almost the same as the number cards in general. However, it has bigger size and brighter colors. This aid is sold for Rp. 55,000.00 per package.

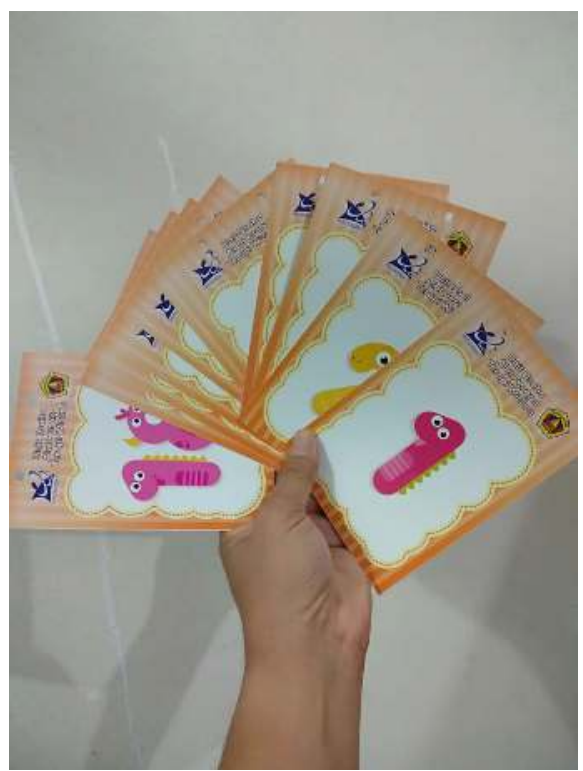

Figure 5.2 Number Cards produced by ABK Speech Therapy Business Unit

This product was sold as many as 344 packages in the first year. The shortcoming of this product is the paper material that is not thick enough.

c. Living object cards

For this living object cards, speech therapy aid business unit UMK produces them in large quantities. In this type of product, there were 223 packages sold in 4 months. Here is the picture of the product. 


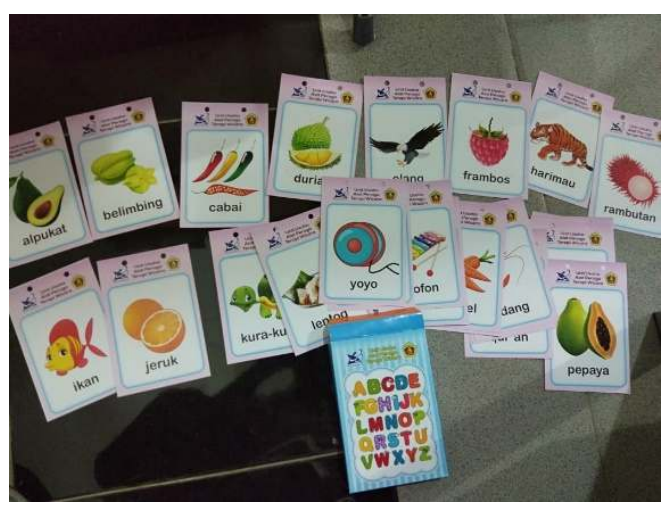

Figure 5.3 Living object card products

d. Hand puppet

This product has a uniqueness since it comes in the form of a hand puppet character wearing Kudus traditional clothes. The product has sold a total of 125 pieces. Here are the designs and products.

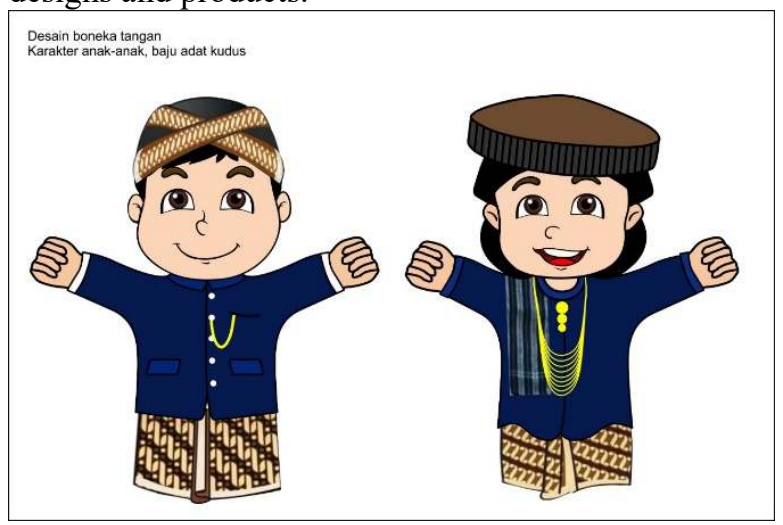

Figure 5.4 Master design of hand puppet characters wearing Kudus traditional clothes

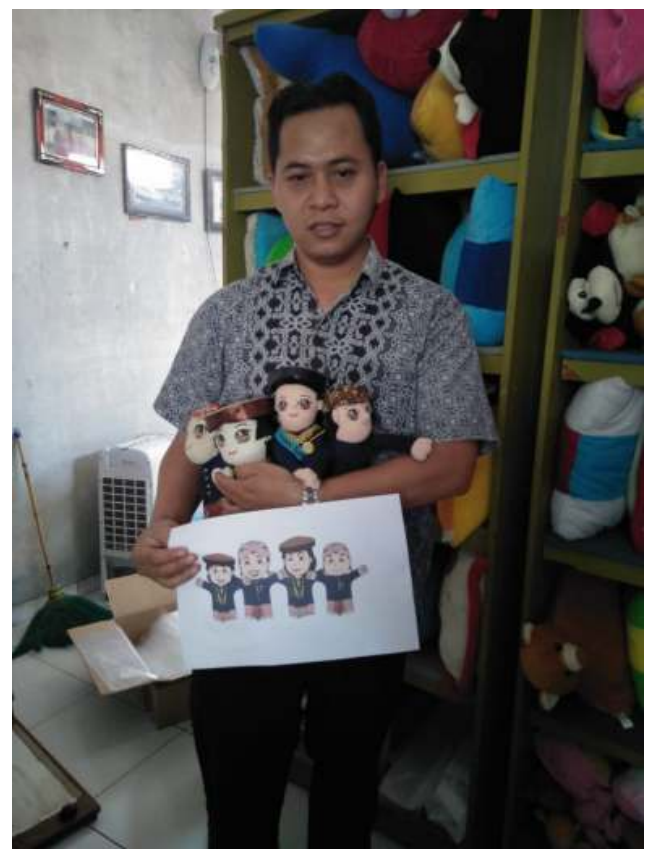


Figure 5.5 Hand puppets of family members wearing Kudus traditional clothes

\section{e. Daily Activity Sequence Accordions}

This product is made from flannel cloth that is designed to last for use by children with special needs. This product has an advantage compared to other accordions, i.e. it includes daily activities by taking the needs of aids for children with special needs into account. This product has been sold for as many as 137 pieces.

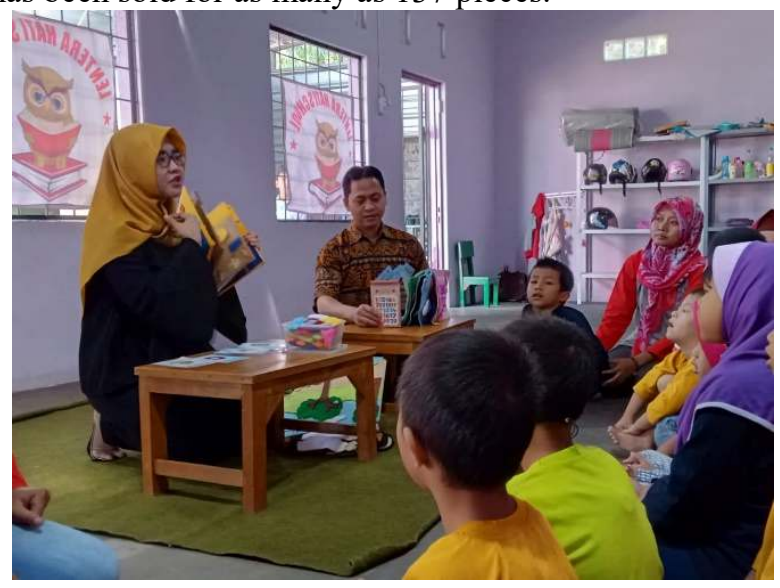

Figure 5.6 Accordion Book is being used for speech therapy

At the production stage, considering the high number of demands, the team encountered difficulties in the provision of raw materials and tools, so the team needed to partner with puppet producers. However, the design and logo are still owned by the public service team. The following is the logo design of speech therapy aids for children with special needs business unit. 

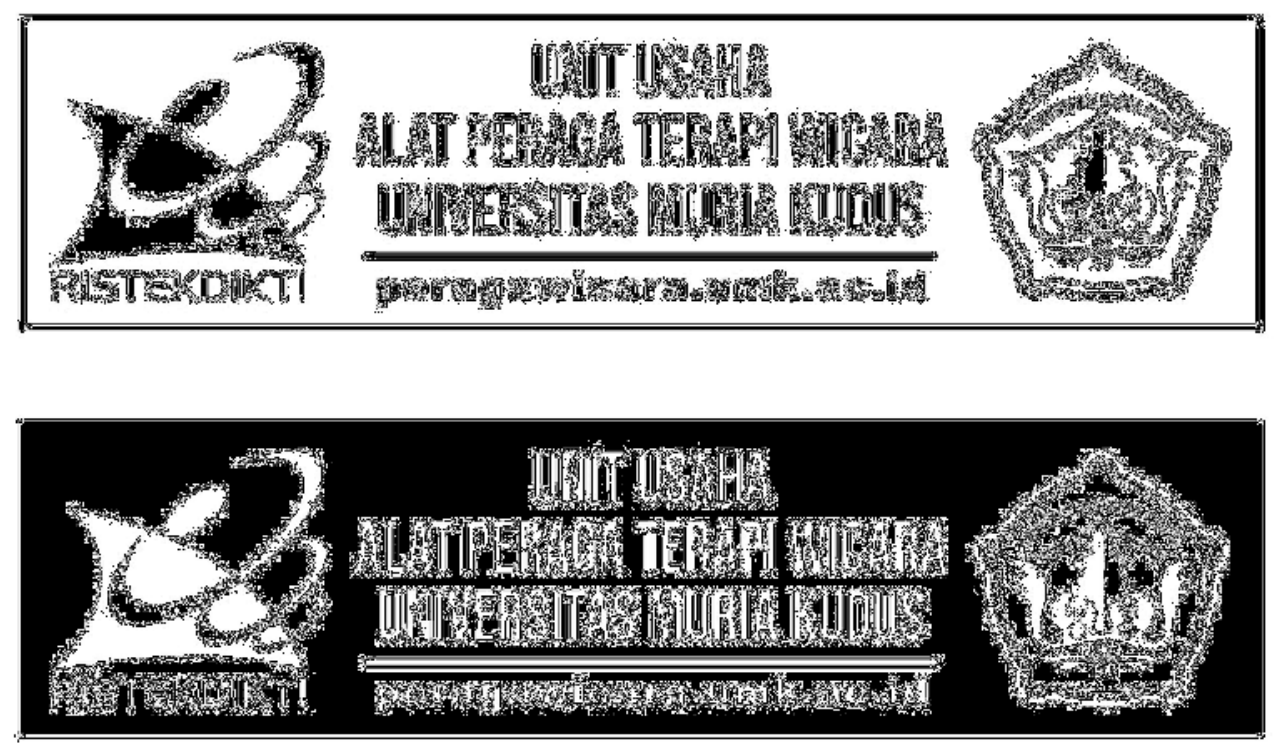

Figure 5.7 Logo of speech therapy teaching aids for children with special needs business unit

At the production stage, the problem is the limited number of workers who manufacture the aids. In addition to the limited number of workers, the limitation of this business process also lies on the marketing process. The marketing process has been carried out in the area of Kudus Regency, Jepara Regency, Demak Regency, Pati Regency, Rembang Regency, etc. The following is the picture of the promotion process at school.

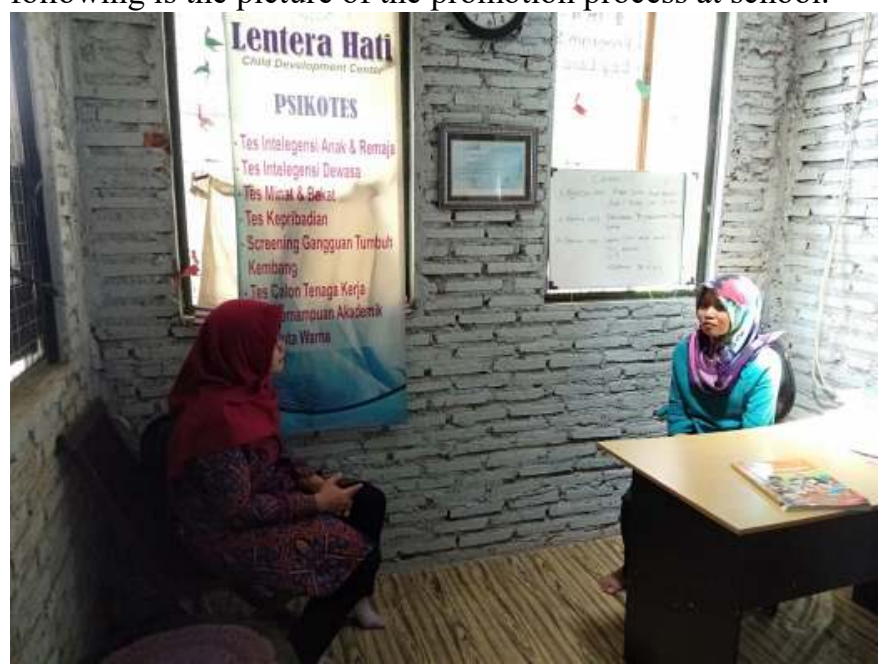

Figure 5.7 Promotion process to Lentera Hati School

In the promotion process, the team also provides the facility of a manual to use the speech therapy aids. The goal is to make it easier for teachers, parents, or therapists to use these aids. 


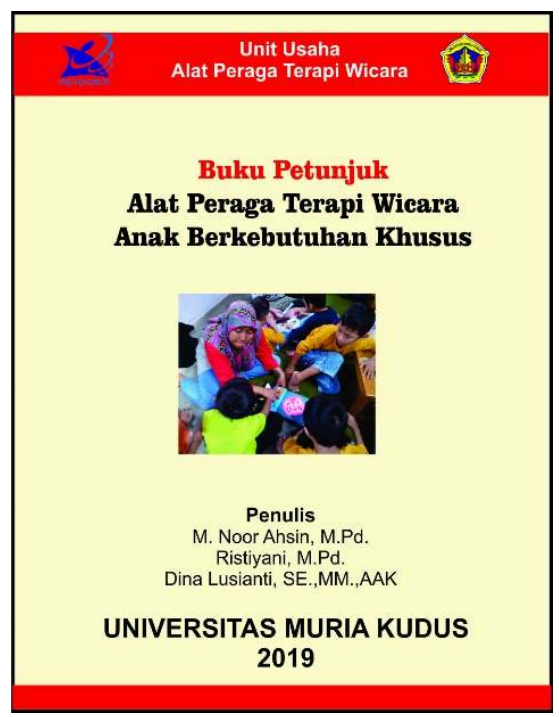

Figure 5.8 Cover of manual book

In addition to selling speech therapy aids, the team also conducts speech therapy training for children with special needs involving teachers of children with special needs at school.

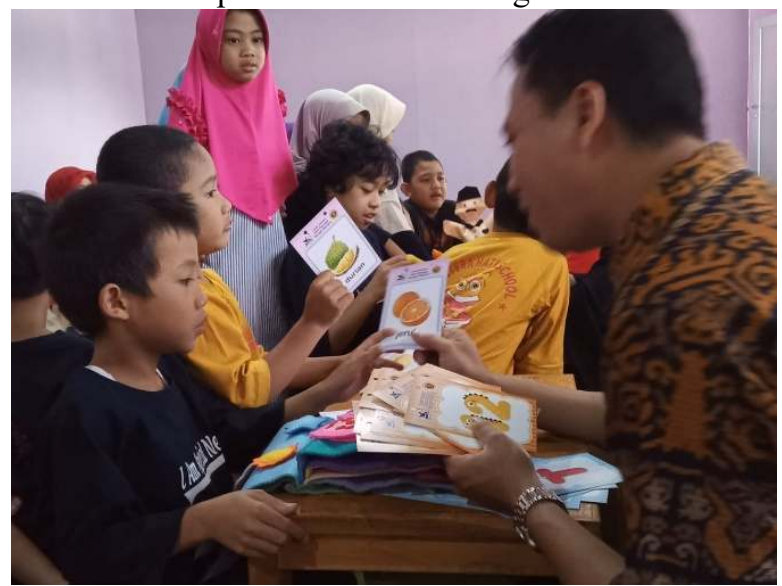

Figure 5.9 Enthusiasm of children with special needs during speech therapy training

Children with special needs are clearly interested in speech therapy aids during the training process. This can be observed in the following picture. 


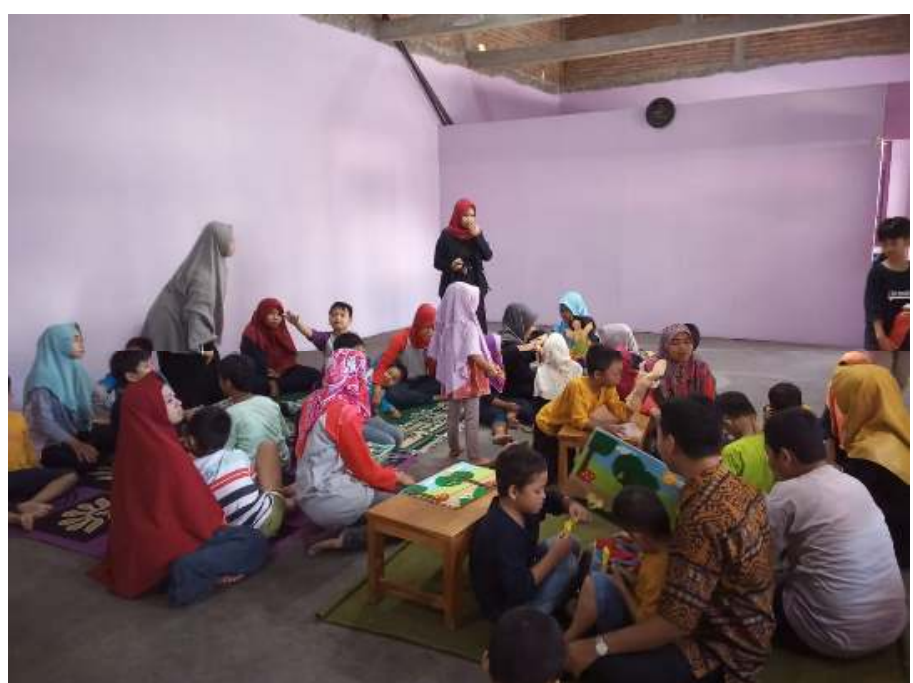

Figure 5.10 Enthusiasm of children with special needs in speech therapy aid products

\section{Conclusions}

1. The aids produced by Speech Therapy Aid Business Unit Muria Kudus University in the first year include 8 products, which are alphabetical cards, color cards, body part cards, daily activity cards, accordion of daily activity sequences, accordion of certain places, hand puppets, and miniatures of living things.

2. The implementation methods include segmentation, production, finance, and HR management.

3. There is high market demand for speech therapy aids for children with special needs.

4. It is necessary to increase the sales promotion on national scale.

\subsection{SUGGESTION}

1. It is necessary to develop improved production management well and establish cooperation with permanent suppliers of high quality raw materials with more efficient and economical costs without reducing the quality of the materials to reduce the production costs and increase the sales.

2. It is necessary to look for reliable suppliers; hence, when the orders increase, the supply of raw materials remains available and controlled so that it does not hamper the production of speech therapy aids.

3. In order to increase and expand the product marketing, it is necessary to have good promotion media.

4. It is necessary to provide computer or software-based speech therapy media.

\section{References}

[1] Feni, Minarni Rama Jura. Ritman Ishak Paudi. The Use of Concrete Aids to Improve the Learning Outcomes of Science Lesson in Grade IV at SDN No.3 Ogoamas I, North Sojol District, Donggala District. The study was published in Kreatif Tadulako Online Journal, vol 5 No.11, pp. 1-13 (2014) 
[2] Grafura, Lubis. Ari Wijayanti. Educational aids: For Attractive Learning. Jakarta: Prestasi Pustaka (2011)

[3] Hamalik, Oemar. Psychology of Learning and Teaching: Assisting Teachers in Planning Teaching, Assessing Behavior, and Providing Ease to Students in Learning. Bandung: Sinar Baru Algensindo (2009)

[4] Handoko. Speech Disorders. Padang: Andalas Dharma University (2014)

[5] Jamal, Mirza. Creative Indoor and Outdoor Games to Boost Children's Intelligence. Yogyakarta: Titan (2010)

[6] Marliyah. Efforts to Improve Learning Outcomes of Science Lesson Through the Use of Concrete Aids in Class 1A Students at SDN Darungan 01, Tanggul District, Jember Regency. The study was published in Pancaran Journal, Vol.3 No.4 November 2014, pp. 153-164 (2010)

[7] Silberman, Mel. Active Learning: 101 Strategies for Active Teaching. Jakarta: Index (2013)

[8] Slameto.. Learning and Factors Affecting it. Jakarta: PT Rineka Cipta. (1995)

[9] Suyadi. Educative aids that Educate: Sharpen Children's Potential with Exciting Game Patterns. Yogyakarta: Power Books (2009)

[10] Yaumi, Muhammad. Multiple Intelligence-Based Learning. Jakarta: PT. Dian Rakyat (2012)

[11] Sunanik. Implementation of Speech Therapy and Sensory Integration Therapy in Children with Late Speech. Samarinda State Islamic High School. Nadwa, Journal of Islamic Education. Vol. 7, Number 1. (2013) 